of the causes which have merged the European and the Far Eastern conflicts into a single war. Sir John Pratt, moreover, in tracing the course of Japanese foreign policy and particularly of Japanese relations with Great Britain, goes to those fundamental differences in national temper and outlook which explain the present hostility of Japan and Great Britain, and indeed raise the question as to the desirability from the start of the Anglo-Japanese Alliance of 1902.

\section{The Indian Science Congress}

THE following have been elected presidents of the various sections of the 1943 session of the Indian Science Congress, to be held in Lucknow during January $2-8,1943$. The fourteen sections into which the Congress originally divided its work have been re. grouped into twelve sections. Mathematics and Statistics, Dr. S. C. Dhar, University of Nagpur ; Physics, Dr. H. J. Bhabha, Indian Institute of Science, Bangalore; Chemistry, Dr. S. S. Joshi, Benares Hindu University; Geology and Geography, Lieut.-Colonel E. A. Glennie, Survey of India, Dehra Dun; Botany, Dr. K. Biswas, Royal Botanical Garden, Sibpur, Calcutta ; Zoology and Entomology, Dr. B. N. Chopra, Zoological Survey of India, Calcutta; Anthropology and Archoeology, Dr. N. Chakravarti, Archæological Survey of India, New Delhi ; Medical and Veterinary Sciences, Dr. F. C. Minett, Imperial Veterinary Research Institute, Mukteswar ; Agricultural Sciences, Rao Bahadur Y. Ramchandra Rao, Imperial Council of Agricultural Research, New Delhi ; Physiology, Dr. B. Narayana, P.W. Medical College, Patna; Psychology and Educational Science, Dr. B. L. Atreya, Benares Hindu University; Engineering and Metallurgy, Prof. K. Aston, Indian Institute of Science, Bangalore.

\section{Night Sky in June}

NEw moon is on June 13d. 21h. 02m. U.T., and full moon on June $28 \mathrm{~d}$. $12 \mathrm{~h} .09 \mathrm{~m}$. Lunar conjunctions with the planets occur as follows: Venus on June 10d. 05h., Venus $2^{\circ}$ N. ; Saturm on June 12d. 08h., Saturn $3^{\circ}$ N. ; Mars on June 17d. 07h. Mars $4^{\circ}$ N. On June 29d. 20h. Venus is in conjunction with Uranus, Venus $1 \cdot 7^{\circ} \mathrm{S}$. Mercury is near the sun during the month and souths at $13 \mathrm{~h} .03 \mathrm{~m}$. and $10 \mathrm{~h} .39 \mathrm{~m}$. at the beginning and end of the month respectively. Venus is a morning star and souths at $9 \mathrm{~h} .22 \mathrm{~m}$. in the middle of the month. Jupiter, in conjunction with the sun on June 25, is too close to the sun to be observed. Saturn is a morning star and souths at the end of the month at $9 \mathrm{~h} .49 \mathrm{~m}$. Only two occultations occur in the month and the brighter of the two stars, 44 Virginis, occulted on June 22d. $22 \mathrm{~h}$. $50 \mathrm{~m}$., is mag. 5.9. The sun enters the sign of Cancer on June 22d. 01h., the summer solstice, and at this time the nights in the latitude of London are about 7 hours long. If civil twilight is taken into consideration (sun $6^{\circ}$ below the horizon) the time of darkness is only $5 \frac{1}{2}$ hours. Conditions for seeing the night skies are very much restricted during the month.

\section{Recent Earthquakes}

A STRONG earthquake was reported on May 23 to have occurred in Colombia, South America. The town of Girardot, some sixty miles south-west of Bogota, is stated to have been partly destroyed, and shortly afterwards the island of Gorgona, in Buena- ventura Bay, was submerged by a huge wave. This part of South America is particularly liable to experience earthquake shocks. Many of these from 1763 until 1936 have been described by J. Emilio Ramirez, S.J., and one reported by the British Association Seismological Committee in 1907 broke submarine cables off the mouth of the Esmeralda. River on January 31, 1906.

The Ecuador earthquake of May 14 was beautifully recorded on the E-W Milne-Shaw seismogram obtained by Rev. J. P. Rowland, S.J., at Stonyhurst. College Observatory. The $P$ wave was impulsive at $02 \mathrm{~h} .25 \mathrm{~m}$. 50s. U.T. and a full suite of pulses followed. The readings are in agreement with the statements in NATURE of May 23, p. 578.

\section{Announcements}

Sir Henry H. Dale, president of the Royal Society, will retire from the post of director of the National Institute for Medical Research on September 30. To succeed him the Medical Research Council has appointed Prof. C. R. Harington, who is at present professor of chemical pathology in the University of London and director of the Graham Medical Research Laboratories in University College Hospital Medical School.

DR. C. G. Darwin, director of the National Physical Laboratory, has been appointed scientific adviser to the Army Council.

The following officers of the Royal Society of South Africa have recently been elected: President, Prof. A. Brown; Hon. Treasurer, Prof. R. W. James; Hon. General Secretary, Dr. A. J. H. Goodwin; Hon. Editor of Transactions, Dr. A. L. du Toit; Hon. Librarian, Prof. E. Nowbery.

THE following appointments in the Colonial Service have recently been made: Mr. C. E. J. Biggs (senior agricultural officer, Uganda), deputy director of agriculture, Tanganyika ; Mr. A. E. Pound, (inspector of produce, Nigeria), agricultural officer, Kenya.

The population of Peru, according to the last official census, taken in 1940, is 7,023,111 inhabitants (Bol. Of. San. Panamericana, January). The female population forms 50.58 per cent, and the male 49.42 per cent. More than half the population, $52 \cdot 89$ per cent, are whites or mulattoes, and $45 \cdot 86$ per cent are Indians, while the Negroes constitute only $0 \cdot 47$ per cent.

IN "Belgium and the War" (Oxford Pamphlets on World Affairs, No. 56. 4d.), Prof. G. N. Clark describes the economics and politics of Belgium before the German invasion of May 1940, as well as the course of Belgian foreign policy in recent years. The latter part of the pamphlet describes the brief campaign of eighteen days and the reasons for the capitulation of the Belgian army; with, finally, an account of the occupation of Belgium, colonial resistance and of the issues which have made the Belgians carry on the struggle against the Axis Powers.

Erratum. In the letter "2-Aminofluorene as Growth Inhibitor for Bacteria and Rats" by F. Bielschowsky and Prof. H. N. Green in Nature of May 9, p. 526, an error in the legend to the graph was overlooked. It should read: "broken line, feeding on 2-acetyl aminofiuorenone; crossed line, 2 -acetyl aminofluorene". 